\title{
Factors of Local Community Participation in Tourism-Related Business: Case of Langkawi Island
}

\author{
Norlida Hanim Mohd Salleh, Mohd Shafiin Shukor, Redzuan Othman, Mohd Samsudin, and Siti Hajar \\ Mohd Idris
}

\begin{abstract}
Tourism development has enabled the involvement of local communities, particularly in tourism-related business. Community involvement is capable of improving the socio-economic status of the locals, especially in removing them from the clutches of poverty. Recognizing the importance of community involvement, this study attempts to identify the factors which can specifically stimulate community involvement in tourism-related business. To achieve these objectives, face to face interviews with local communities using questionnaire as the study instrument has been conducted. Data was analyzed through the utilization of Statistical Package for the Social Science (SPSS) and Analysis of Moment Structure (AMOS). The results showed that the involvement of local communities in tourism-related business is influenced by two factors, namely income and encouragement from family. These factors are also assisted by other factors, namely self-confidence, interest and opportunity available in Langkawi.
\end{abstract}

Index Terms-Determining factors, local community participation, tourism-related business, Langkawi Islands.

\section{INTRODUCTION}

The importance of community involvement in tourism development has been agreed by most researchers in this field. According to [1], a community drives the development of tourism. In the context of ecotourism, the environment will be conserved with the involvement of the community because the community is more aware on the extent to which the environment should be developed in regard to tourism related activities.

In local communities' involvement, enabling them to reap the benefits from the development that is happening around their neighborhood is of the utmost importance. One of the beneficial impacts to the community is the change in the socio-economic status [2]. For example, in the context of Langkawi Island, before the development of tourism in Langkawi, most of the locals were involved in fishing and farming. However, with the establishment of tourism sector, they had shifted to better economic sector especially to the tourism sector. In this sector, some of them work in resorts, as tourist guides and establish tourism related businesses [3].

In addition, community participation in the tourism sector is seen as capable in sustaining tourism development [4]. This is also supported by the World Tourism Organization

Manuscript received January 25, 2015; revised May 14, 2015.

The authors are with the School of Economics Studies, Faculty of Economics and Management, Universiti Kebangsaan Malaysia, 43600 Bangi, Selangor Darul Ehsan, Malaysia (e-mail: norlidahanim@gmail.com, ikhwan_6101@yahoo.com, moss@ukm.edu.my,shmihajar@gmail.com).
(WTO), World Travel and Tourism Council (WTTC) and the Earth Council [5]. Series of discussions by researchers clearly show that the development of tourism should not only be considered from the economic aspects or profitability alone, but more importantly it is developed in a sustainable manner through community participation.

Here, entrepreneurs and business activities serve as catalysts for economic development of the local communities, as well as guarantors to the continuity of the economy especially in the island [6], [7]. The community has gained the benefit from the tourism development. The locals are given the priority in the substantial number of job opportunities in the tourism business activities. This to prevent them from being marginalized, remain in the traditional economic activities and have no process of economic change. The failure to incorporate the local community will result in continuous poverty among the locals [8] where this will eventually lead to negative effects of tourism development on the population, and retarding its future success [9]. Based on these facts, community participation must be encouraged.

Hence, this study attempts to identify the factors that promote community participation in the tourism industry. By knowing these factors, a relevant policy can be proposed in order to enhance community participation in the tourism industry either in Langkawi or other tourist destinations. The structure of this paper is of the following order: i) introduction ii) background of tourism development in Langkawi Island, iii) research framework, iv) research methodology, v) findings and vi) conclusion and policy implications.

\section{BACKGROUND OF TOURISM DEVELOPMENT IN LANGKAWI ISLAND}

The tourism industry is a significant industry as it acts as an agent to economic growth. Most countries consider tourism industry as a key industry that requires strategic and development planning for it to remain efficient in the modern world and bring in more benefits to the country and the local communities in the country [10].

The tourism industry in Langkawi also has proven itself to be a major revenue earner for the country in terms of total revenue generated. In 2010, this industry showed that the total revenue collected increased by 4.9 per cent from RM6.8 billion in 2009 to RM7.1 billion as reported by the Langkawi Development Authority (LADA).

This achievement is due to the seriousness of various parties, especially the Ministry of Tourism Malaysia in introducing and promoting Langkawi as a popular tourism 
destination that should be visited, both by the national (domestic) and international tourists.

To date, various tourism products have been developed as tourist attractions in Langkawi by LADA or by some other agencies. Several major tourist attractions in Langkawi are: Kilim Geopark, Langkawi Oriental Village, Cable Car, Laman Padi Langkawi, Langkawi Handcraft Complex, Langkawi and underwater Chenang Beach, refer Fig. 1.

The impact of these activities/attractions can be seen when the number of tourist arrivals from 2007-2010 to Langkawi always exceeded 2.3 million tourists [11]. However, the development of tourism industry is meaningless if it is not able to reduce the economic gap of the local communities. This problem always occurs in tourism industry that does not procure the involvement of local communities in tourism development. According to a study conducted by [12], he found that community involvement in the current development of tourism industry is often regarded as the key to a stable development (sustainable). Moreover, communities are expected to share some of the benefits (such as employment and income growth) and cost reduction (due to low wages).

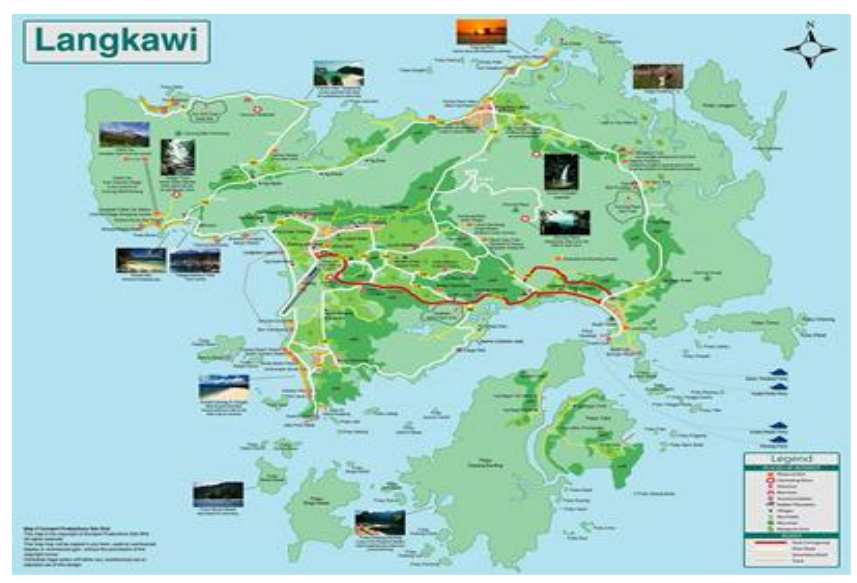

Fig. 1. Map of Langkawi Island and tourism attractions.

Therefore, there is a need for community participation in the development's mainstream. Entries will not only increase the income of the tourism industry itself, but more importantly, to spread the benefits to the local communities [13], [14]. In the long term, this will indirectly guarantee the sustainability of their lives and enable them to be independent in the development mainstream of tourism industry [10].

In 2011, there were 1459 businesses registered with the Companies Commission of Malaysia. This figure increased to 1547 in 2012, and improved to 1633 in 2013. Until September 2014, about 1200 entrepreneurs operating in the Langkawi Island had registered with the said commission. There are a huge number of participations, and if this figure can be sustained, it will increase the socio-economics' status of Langkawi communities. As such, participation should be encouraged by the stakeholders.

\section{RESEARCH FRAMEWORK}

Studies of local community participation can be described as follows. From Fig. 2, it appears that the development of tourism industry and the community in Langkawi should be connected to each other. This means that the development of the tourism industry should provide a space for the community to get involved. Through community involvement, the tourism industry will continue be developed and sustained.

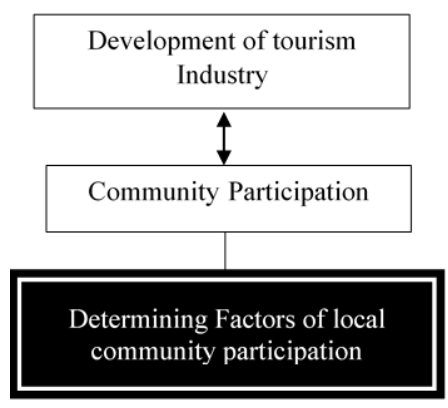

Fig. 2. Research framework of community participation in tourism development.

Based on this research framework, this study is trying to accomplish the following objectives:

1) Review the profile and types of local communities' businesses in tourism.

2) Determine the factors that influence local community participation in tourism.

\section{A. Location, Sampling and Research Instrument}

This study is based on field work in Langkawi. In detail, this study was conducted in several major business areas namely Kuah Town in Langkawi, Padang Mat Sirat, Ayer Hangat, Ulu Melaka, Kedawang, and Bahor. A total of 282 local communities were involved in the study.

Face-to-face interview using questionnaire as the research instrument had been used. The questionnaire was in Malay and divided into several parts. The first part was on the socio-demographic of the respondents/local community; which included gender, age, race, marital status, religion, and background levels of education. The second part was related to the involvement of local communities in tourism-related businesses, which was related to the six main factors, namely, income, family, opportunity, confidence level and interest. A few items which served as the proxy to the stimulus variables were also investigated in this research. The independent variables were determined based on previous studies and evaluation is based on a 5- point Likert scale from 1-"Highly Not Important" to 5- "Highly Important".

\section{B. Study Analysis}

This study employed the Statistical Package for the Social Science (SPSS) and Analysis of Moment Structure (AMOS) software. SPSS was used to analyze the demographic profile of the local communities using descriptive statistical frequency test. The mean analysis was conducted to analyze the independent variables. The mean value was used to describe the average level of agreement by the respondents against the factors that stimulate their local community involvement. Using a five-point Likert scale, scale mean under 2.5 is classified as non-essential; while mean scale of 2.5 and above is considered as important [14]

AMOS software was used for Structural Equation Modeling method (SEM). SEM was utilized in order to explain the structure of the linear equation which represents 
the causal relationship between variables. SEM has two methods, which are exploratory analysis of Factor Analysis (EFA) and Confirmatory Factor Analysis (CFA).

EFA was used to filter unimportant independent variables in order to form a new cluster factor. Items that are not important and do not achieve the desired value will be deleted from these factors; and this is dependent to value of the loading factor, i.e. the standardized estimated value of the AMOS software. The standardized estimated value must equal or exceed [17].

Next, the reliability test (Cronbach's Alpha) should be performed. The test is conducted in order to determine whether the factors that have been developed (from a group of items) fulfill the requirement of the process in forming a factor construct. Here, CA 0.6 is considered to be an acceptable value. Meanwhile, previous researchers have determined that CA between 0.6 and 0.7 as moderate; the CA between 0.7 dan 0.8 as good; $C A$ value between 0.8 and 0.9 as very good; and the CA value of above 0.9 as excellent [16].

In testing the validity of the proposed model, AMOS will be used in the testing of model fit (goodness of fit). Basically, the model validation tests carried out were based on the chi square. Chi square test is the most objective method for the validation of the model [19]. However, some researchers used other indices together with the chi square test. This is because in the case of large sample size, the chi square tends to generate a large value $(>2.0)$, but it is still acceptable if the value does not exceed 5.0. To solve the problem of model validation, most researchers including this study will use the fit indices. These indices include the goodness-of-fit index (GFI), adjusted goodness-of-fit index (AGFI), parsimony goodness fit index (PGFI), normalized fit index (NFI), comparative fit index (CFI), root mean square residual (RMSR) and root mean square error of approximation (RMSEA) [16], [19].

\section{Research Model and Hypotheses Development}

The first objective of this study is to identify the type of tourism-related business activities entered by the community of the island of Langkawi. This can be discovered through interviews conducted with respondents.

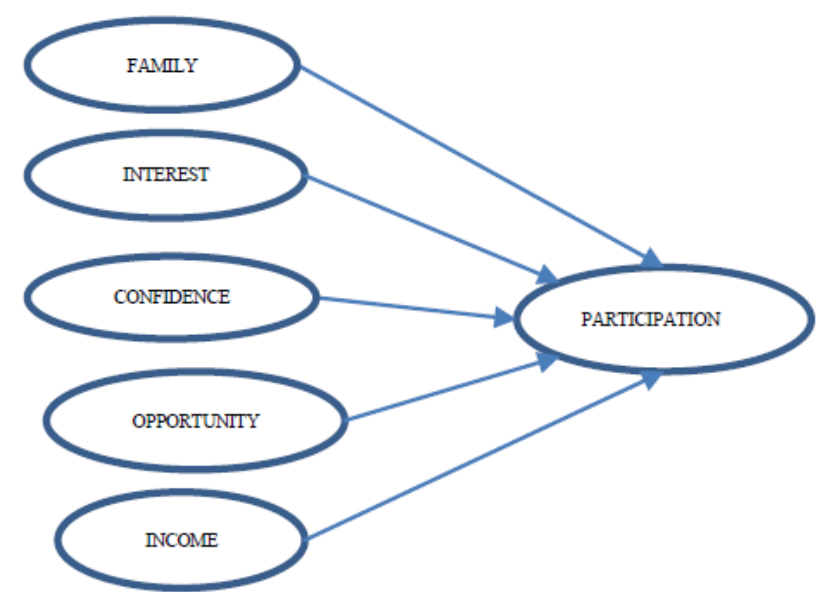

Fig. 3. A proposed model of the determinant factors of local community participation in tourism-related business: Case of Langkawi Island.

Nonetheless, in order to achieve the second objective, the information from the interviews should be analyzed before a conclusion can be made. The conclusions are on factors that influence the local community participation in the tourism related business. Initially, for this purpose, all the variables namely family, passion, confidence, opportunity and opinions are expected to be factors that stimulate the community to be involved in tourism-based businesses in Langkawi Island. This relationship is illustrated by Fig. 3.

H1: There is positive relationship between family encouragement and participation in business

$\mathrm{H} 2$ : There is positive relationship between interest and participation in business

H3: There is positive relationship between confident and participation in business

H4: There is positive relationship between opportunity and participation in business

H5: There is positive relationship between income and participation in business.

\section{EMPIRICAL FINDINGS}

The study began with a discussion on the socio demographic profile of local community. This is followed by the discussion on profile and types of local communities businesses and factors that influence the local community participation in the tourism related business.

\section{A. Socio Demographic Profile}

Based on Table I, results from field study show that the local communities consist of $45.4 \%$ male and $54.6 \%$ female. The age of local communities involved in tourism related business is between 21 to 67 years. In terms of the local communities' age, it is found that those aged 31-40 years were at $35.1 \%, 21-30$ years at $34.4 \%$ and $41-67$ years at $30.5 \%$.

Majority of them were Malays with a percentage of $76.6 \%$, followed by the Chinese at $21.3 \%$. Overall, the $72.7 \%$ were married and $23.4 \%$ were singles. In Malaysia, Malay is synonymous with being Muslims, thus, the majority of the local communities in this study were Muslims (78\%). In terms of education level, $58.2 \%$ of the respondents had a minimum level of education and possessed a certificate of education, $17 \%$ were diploma holders and $8.3 \%$ had a degree.

\section{B. Review on the Profile of Local Communities' Businesses}

Based on Table II, there are 4 main profiles to the tourism related business surveyed in the study; namely year business starts, start-up capital, type of business and the monthly income.

In general, the commencement of Langkawi local communities' participation in businesses is the year 2000 . This is because the year 2000 was the year when the government started to actively implement development programs in PulauLangkawi until it is recognized as a member of the Global Geoparks Network [21]. Thus, many business opportunities are available to local communities.

Meanwhile, in terms of the business's start-up capital, most local communities obtained their financial support through personal savings (84.2\%), financial resources/capital from bank loans $(21.2 \%)$, and family loans (18.6\%). This means majority of the local communities start their businesses with their own resources and are not bound by 
financial organizations.

TABLE I: DEMOGRAPHIC PROFILE AND TYPE OF LOCAL COMMUNITIES

\begin{tabular}{|c|c|c|}
\hline Demographic & Frequency & Percentage (\%) \\
\hline \multicolumn{3}{|l|}{ Gender } \\
\hline Male & 128 & 45.4 \\
\hline Female & 154 & 54.6 \\
\hline \multicolumn{3}{|l|}{ Age } \\
\hline $21-30$ & 97 & 34.4 \\
\hline $31-40$ & 99 & 35.1 \\
\hline $41-67$ & 86 & 30.5 \\
\hline \multicolumn{3}{|l|}{ Ethnic } \\
\hline Malay & 216 & 76.6 \\
\hline Chinese & 60 & 21.3 \\
\hline India & 4 & 1.4 \\
\hline Others & 2 & 0.7 \\
\hline \multicolumn{3}{|l|}{ Marital Status } \\
\hline Single & 66 & 23.4 \\
\hline Married & 205 & 72.7 \\
\hline Divorced & 11 & 3.9 \\
\hline \multicolumn{3}{|l|}{ Region } \\
\hline Islam & 220 & 78.0 \\
\hline Christian & 9 & 3.2 \\
\hline Buddha & 46 & 16.3 \\
\hline Hindu & 6 & 2.1 \\
\hline Others & 1 & 0.4 \\
\hline \multicolumn{3}{|l|}{ Education } \\
\hline No certificate & 20 & 7.1 \\
\hline Primary School & 13 & 4.6 \\
\hline High School & 14 & 5.0 \\
\hline Certificate & 164 & 58.2 \\
\hline Diploma & 48 & 17 \\
\hline Degree & 23 & 8.3 \\
\hline
\end{tabular}

TABLE II: PRofiLE AND TyPe OF LOCAL COMMUNITIES BUSINESS IN

\begin{tabular}{|c|c|c|c|}
\hline \multicolumn{4}{|c|}{ TOURISM } \\
\hline Information & & Item & $\begin{array}{l}\text { Percentage } \\
(\%)\end{array}$ \\
\hline \multirow{3}{*}{$\begin{array}{l}\text { Year of } \\
\text { business } \\
\text { operates }\end{array}$} & 1. & Before 1987 & 5.6 \\
\hline & 2. & $1987-2000$ & 28.4 \\
\hline & 3. & After 2000 & 66.0 \\
\hline \multirow{6}{*}{$\begin{array}{l}\text { Venture } \\
\text { Capital }\end{array}$} & 1. & Personal savings & 84.2 \\
\hline & 2. & Financing from & 21.2 \\
\hline & 3. & $\begin{array}{l}\text { banks } \\
\text { Loanfrom spouse/ } \\
\text { family/relative }\end{array}$ & 18.6 \\
\hline & 4. & $\begin{array}{l}\text { AmanahIkhtiarl } \\
\text { Mara }\end{array}$ & 8.0 \\
\hline & 5. & Illegal money lender & 0.2 \\
\hline & 6. & Others & 11.0 \\
\hline \multirow{7}{*}{$\begin{array}{l}\text { Type of } \\
\text { business }\end{array}$} & 1. & Accommodation & 5.8 \\
\hline & 2. & Retail & 42.8 \\
\hline & 3. & Wholesale & 2.8 \\
\hline & 4. & Transport & 6.4 \\
\hline & 5 & & 26.4 \\
\hline & 5. & Restaurant & 15.8 \\
\hline & 6. & Services & \\
\hline \multirow{6}{*}{$\begin{array}{l}\text { Annual Net } \\
\text { income }\end{array}$} & 1. & Below 2000 & 7.8 \\
\hline & 2. & $2001-4000$ & 28.8 \\
\hline & 3. & $4001-6000$ & 26.0 \\
\hline & 4. & $6001-8000$ & 17.6 \\
\hline & 5 . & $8001-10000$ & $6 . .0$ \\
\hline & 6. & Above 10000 & 13.8 \\
\hline
\end{tabular}

Several types of businesses often taken up by local communities are accommodation, retailing, wholesaling, transportation, restaurants and other tourism-related support services. Majority of the local communities are involved in retail $(42.8 \%)$. This type of business does not require huge capital, and it is sufficient through private fund. Second, those who are involved in food preparation, i.e. restaurant at $26.4 \%$. In view that Langkawi is a tourism center, the provision of food is very necessary. However, the business of serving food (restaurant) is very competitive as there are also food operators of hotels, resorts and chalets. Other types of business recorded a smaller percentage of participation ranging from 2 to $16 \%$.

These findings also showed only $7.8 \%$ of the local communities involved in businesses in Langkawi earned below RM2,000. This shows that only a small percentage is earning below the poverty line. For those earning above RM2,001, the percentage was $92.2 \%$. These findings indicate that the involvement of local communities in businesses has been successful in reducing poverty in Langkawi.

\section{Determining Factors of Local Community Participation in Tourism Related Business}

The factors that determine local community participation in tourism related business are shown in Table III. Based on that table, few analyses/statistical tests have been conducted. Those are: the mean analysis for each of the items, standardized estimated test, reliability test and the mean analysis of the construct, as well as the model validation tests.

\section{Mean Analysis of Each Items}

Based on the mean analysis of the family factor, the mean range is between 3.55 and 3.83. In detail, encouragement from friends and family as well as providing the spot for business by family members registered mean value of 3.83 each. These are followed by encouragement from family members (3.61). For continuing family business and the desire to have a business to be passed to children, their mean is at 3.55 .

Further, participation is no doubt influenced by income. This is because the local communities' involvement in tourism related businesses is because they expect to earn more money. This item shows the highest mean value at 4.08. In addition, by being involved in businesses, they stated that the business can brings in additional income to themselves as well as to family with mean values at 3.97 and 3.98 , respectively. The item where the respondents expected to obtain high profit recorded a mean value of 3.88 .

Interest in business is also an important factor. In fact, this statement is supported in most previous studies, such as [21]. The main item that should be included in this factor is the passion to run a business (4.17). Second, participation in the business allows them to make drastic decisions independently and without being bound by any party (4.03). The community also felt that being a business owner is something to be proud of (3.88).

Self-confidence is needed by the local communities to enable them to venture into businesses and in other areas as well. Thus, the community stated that being confident is an important stimulus for business (4.03). Second, in an effort to build self-confidence, local communities stated that they should be prepared to improve the situation when there is a complaint from a customer. Knowledge/skill is the lowest item. However, these items are still at a high level of agreement (3.89).

For the opportunity factor, local communities stated that there are huge business opportunities in Pulau Langkawi 
(4.03) that should be explored. Second, they need to take advantage of the good economic environment (3.94). Third, local communities felt that going into business will give more time (3.82) as compared to other occupations that are bound by working hours. These results are similar to the findings by [25] in which most of them became businessmen as they want to work independently.

External support to businessmen also needs to be considered. This support encompasses the aspects of financial assistance from the government and banks, and the support to obtain start-up capital, raw materials and labor. The local communities stated that the financial assistance from the government and banks is an important item to boost their businesses. The study conducted by [24] showed that financial factor is important to businesses and financial assistance from commercial banks is also needed to expand or grow business.

\section{E. Standardized Estimated Test}

After testing the mean of the items for the factors, the next tests are the standardized estimated test (factor analysis) by using AMOS 5. Based on Table IV, the test found that 2 of the 5 items for family factors are eliminated because their loadings were lesser than 0.4. Meanwhile, the loading of items for income ranges between 0.51 and 0.65 . These values indicate that no item is to be deleted. Further, the item, interest showed loading factor exceeding 0.40 , i.e. between 0.51 and 0.67 . As for the confidence factor, it has 7 variables and the loadings of the items were in the range of 0.44 to 0.72 . Standardized tests for all three items for interest factor found that the loadings were at $0.51,0.66$ and 0.68 . For the stimuli for business involvement from external influence factors, 2 items were removed as they did not meet the requirements.

\section{F. Reliability Test}

The reliability test, Cronbach Alpha (CA) indicated that all the constructed factors were between 0.62 and 0.85 . These values showed that these factors have correlations that are of medium, high, and very high strength to build the constructs as suggested by [16]. There was no construct eliminated.

\begin{tabular}{|c|c|c|c|c|c|}
\hline \multirow[t]{2}{*}{ Factors/Items } & \multirow{2}{*}{\multicolumn{2}{|c|}{ 营 }} & \multirow[b]{2}{*}{ 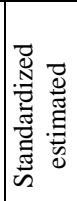 } & \multirow[b]{2}{*}{ 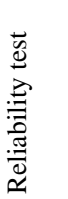 } & \multirow[b]{2}{*}{ 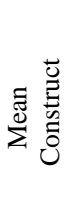 } \\
\hline & & & & & \\
\hline Family & & & & 0.65 & 3.74 \\
\hline 1. Encouragement from friends & 3.83 & $(0.90)$ & 0.60 & & \\
\hline $\begin{array}{l}\text { 2. Family provides the business } \\
\text { spot }\end{array}$ & 3.83 & $(0.89)$ & 0.60 & & \\
\hline $\begin{array}{l}\text { 3. Encouragement from family } \\
\text { to start business }\end{array}$ & 3.61 & $(1.06)$ & $\mathrm{X}$ & & \\
\hline 4. To continue family business & 3.55 & $(1.10)$ & 0.66 & & \\
\hline $\begin{array}{l}\text { 5. To pass the business to } \\
\text { children }\end{array}$ & 3.55 & $(0.99)$ & $\mathrm{X}$ & & \\
\hline Income & & & & 0.70 & 3.98 \\
\hline 1. To earn better income & 4.08 & $(0.80)$ & 0.65 & & \\
\hline 2. To earn additional income & 3.97 & $(0.84)$ & 0.62 & & \\
\hline 3. Expecting high profit & 3.88 & $(0.84)$ & 0.65 & & \\
\hline 4. Increase family income & 3.98 & $(0.80)$ & 0.51 & & \\
\hline Interest & & & & 0.62 & 4.04 \\
\hline 1. Like to operate a business & 4.17 & $(0.75)$ & 0.60 & & \\
\hline 2. Free to decide & 4.08 & $(0.74)$ & 0.67 & & \\
\hline
\end{tabular}

\begin{tabular}{|c|c|c|c|c|c|c|}
\hline \multirow{2}{*}{\multicolumn{2}{|c|}{ 3. Proud to be a businessman }} & 3.88 & $(0.78)$ & 0.51 & & \\
\hline & & & & & \multirow[t]{8}{*}{0.81} & \multirow[t]{8}{*}{3.95} \\
\hline 1. & Possess self confidence & 4.03 & $(0.76)$ & 0.58 & & \\
\hline 2. & $\begin{array}{l}\text { Eager to improve when } \\
\text { there is a customer } \\
\text { complain }\end{array}$ & 3.91 & $(0.70)$ & 0.72 & & \\
\hline 3. & Not giving up easily & 3.97 & $(0.78)$ & 0.54 & & \\
\hline 4. & Prefer to operate a business & 3.94 & $(0.75)$ & 0.62 & & \\
\hline 5. & $\begin{array}{l}\text { Practice the knowledge } \\
\text { learned }\end{array}$ & 3.96 & $(0.72)$ & 0.72 & & \\
\hline 6. & To measure own capability & 3.93 & $(0.66)$ & 0.68 & & \\
\hline 7. & $\begin{array}{l}\text { Possess business } \\
\text { knowledge/skill }\end{array}$ & 3.89 & $(0.82)$ & 0.44 & & \\
\hline \multicolumn{2}{|c|}{ Opportunity } & & & & \multirow[t]{4}{*}{0.64} & \multirow[t]{4}{*}{3.93} \\
\hline 1. & $\begin{array}{l}\text { Not willing to be subjected } \\
\text { to office hour }\end{array}$ & 3.82 & $(0.93)$ & 0.66 & & \\
\hline 2. & $\begin{array}{l}\text { Opportunity to operate a } \\
\text { business }\end{array}$ & 4.03 & $(0.83)$ & 0.51 & & \\
\hline 3. & $\begin{array}{l}\text { Taking advantage of good } \\
\text { economic environment }\end{array}$ & 3.94 & $(0.71)$ & 0.68 & & \\
\hline \multicolumn{2}{|c|}{ Stimulus/Participation } & & & & \multirow[t]{7}{*}{0.85} & \multirow[t]{7}{*}{3.29} \\
\hline & $\begin{array}{l}\text { Easy access to government } \\
\text { support }\end{array}$ & 3.29 & $(1.14)$ & 0.89 & & \\
\hline 2. & $\begin{array}{l}\text { Easy access to bank } \\
\text { financing }\end{array}$ & 3.32 & $(1.08)$ & 0.88 & & \\
\hline 3. & $\begin{array}{l}\text { Easy to obtain start-up } \\
\text { capital }\end{array}$ & 3.43 & $(1.03)$ & 0.73 & & \\
\hline 4. & $\begin{array}{l}\text { Family's asset such as land } \\
\text { as collateral makes it easier } \\
\text { for me to raise the start-up } \\
\text { capital for business }\end{array}$ & 3.14 & $(1.27)$ & 0.61 & & \\
\hline 5. & $\begin{array}{l}\text { Easy to procure } \\
\text { supply/material for } \\
\text { business }\end{array}$ & 3.72 & $(0.79)$ & $\mathrm{X}$ & & \\
\hline 6. & $\begin{array}{l}\text { Easy to obtain quality } \\
\text { employee }\end{array}$ & 3.59 & $(0.96)$ & $\mathrm{X}$ & & \\
\hline
\end{tabular}

\section{G. Mean Analysis of the Construct}

For the mean test for each factor's constructs, all the factors had high agreement level, i.e. between 3.74 and 4.04. Interest was the most dominant factor in stimulating them into businesses (4.04). Second, they were involved in businesses in order to earn an income (3.98). Moreover, the local community felt that self-confidence has to be at the third place (3.85). In involving in businesses, they need to grab the opportunity given (3.93). Finally, family support is needed as to ensure continuity in business (3.74).

\section{H. Model Validation Tests}

The goodness of fit's results on the tested models did not fulfill the requirement. Thus, this model was modified in order to obtain an acceptable result. As a result of the modification, the chi square value was found to be at 2.50 at significance level of $p=0.01$. This value exceeded the requirement of 2.0. Thus, the goodness of fit test confirmed that this model is acceptable. The goodness of fit tests, GFI, AGFI, PGFI, TLI, and NFI showed values of $0.863,0.825$, $0.673,0.877$ and 0.810 , respectively. These results exceeded the suggested value of 0.700 and 0.500 [16]. Thus, these indicate that the suggested model suits the sample data.

Additionally, the alternative indices were also utilized to evaluate the fit model, i.e. RMSEA, RMSR and CFI. Results were: RMSEA (0.076), RMR (0.076) and CFI (0.875). The alternative fit index CFI indicates that the structure of the model is acceptable and the data is suitable to the model (Table IV). 
TABLE IV: GOODNESS OF FIT INDICES OF MEASUREMENT MODEL AND THE

\begin{tabular}{|c|c|c|c|}
\multicolumn{5}{|c}{ STRUCTURAL MODEL $(N=282)$} \\
\hline$X^{2}$ Test & Criteria & Error & $\begin{array}{c}\text { Modification of } \\
\text { SEM }\end{array}$ \\
$X^{2} / \mathrm{df}$ & $<5.000$ & $4.11=(1011.70 / 246)$ & $2.50=(585.35 / 234)$ \\
Fit indices & & & \\
GFI & $>0.800$ & 0.778 & 0.863 \\
AGFI & $>0.800$ & 0.730 & 0.825 \\
PGFI & $>0.500$ & 0.638 & 0.673 \\
TLI & $>0.800$ & 0.694 & 0.877 \\
NFI & $>0.800$ & 0.672 & 0.810 \\
& & & \\
Alternative & & & \\
indices & & & \\
CFI & $>0.900$ & 0.727 & 0.875 \\
RMSEA & $<0.080$ & 0.105 & 0.073 \\
RMR & $<0.080$ & 0.102 & 0.076 \\
\hline
\end{tabular}

\section{Findings of the Structural Model Parameter}

Table V and Fig. 4, depict the empirical test indicate as to whether these results support the constructed hypotheses or otherwise. Based on the empirical results, it is found that the engagement or participation of respondents in business is not directly based on the Fig. 3. It involves a linkages between factors before the respondents had a decision to be engaged/participated in tourism-related business. Study by Deniz, et al., (2011), also proven that the empirical model do not exactly followed the proposed model.

Finding such as Fig 4, shown that there is presented of relationship between interest and income. Results showed that there was a positive correlation, where $\alpha=0.85, t=2: 38$ at the significance level of 0.025 .

Meanwhile, test also indicates on relationship between confidence and income. The results showed that there is positive correlation with t-statistics of $\beta=0.45,3.038$ at significance level of 0.002 . Additionally, the relationship between opportunity and income also showed positive relationship $(t=4.845, p=0.00)$. The study conducted by [26] also supports that respondents involved in businesses are willing to face risks, armed with their confidence.

The results showed that local communities stated that interest, confidence and opportunities separately and positively interact with income and directly encourage them to be involved in tourism related business.

Meanwhile, income factor directly affects the community's involvement in business. The relationship between income and participation indicate a positive correlation, where, $\gamma=0.28, t=2.138$ at significance level 0.033 . This suggests that those involved in the business expect a lucrative income. These empirical results are similar to the findings of a study done by [27] where he stated that the reason the respondents engaged in businesses is economic profit.

Results on the link between family relationship and opportunity showed that there is a positive relationship, i.e. $\Omega=0.26$, t-test of 2.102 with significance level at 0.036 . Additionally, it also showed that family has a direct relationship with business opportunity.

Further, the relationship between family and participation was found to be positive ( $\partial=0.42 t=2.916, p=0.004)$. The test result indicates that family is highly important in stimulating them to be involved in business. The study by [29] also noted that entrepreneurial tradition in the family (parents, brothers) is important in supporting the respondents in businesses.

Overall, it can be concluded that those who are involved in the business are influenced by income and encouragement from family. Hypothesis 1 and 5 are directly supported. Meanwhile, income also relates to either, interest, confidence or opportunity to become a stimulant to the community to be involved in tourism related business.

\begin{tabular}{|c|c|c|c|c|c|c|}
\hline 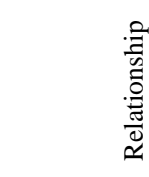 & & & 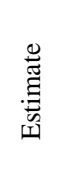 & 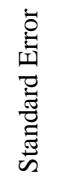 & 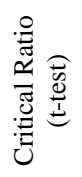 & $\begin{array}{l}\stackrel{0}{\Xi} \\
\frac{\pi}{\pi} \\
D^{\prime}\end{array}$ \\
\hline Income & $<$ & Interest & 0.848 & 0.878 & 2.238 & 0.025 \\
\hline Income & & Confidence & 0.498 & 0.264 & 3.038 & 0.002 \\
\hline Opportunity & & Income & 0.827 & 0.237 & 4.845 & $* * *$ \\
\hline Stimulus & & Income & 0.277 & 0.478 & 2.138 & 0.033 \\
\hline Opportunity & $<$ & Family & 0.258 & 0.080 & 2.102 & 0.036 \\
\hline Stimulus & & Family & 0.420 & 0.249 & 2.916 & 0.004 \\
\hline
\end{tabular}

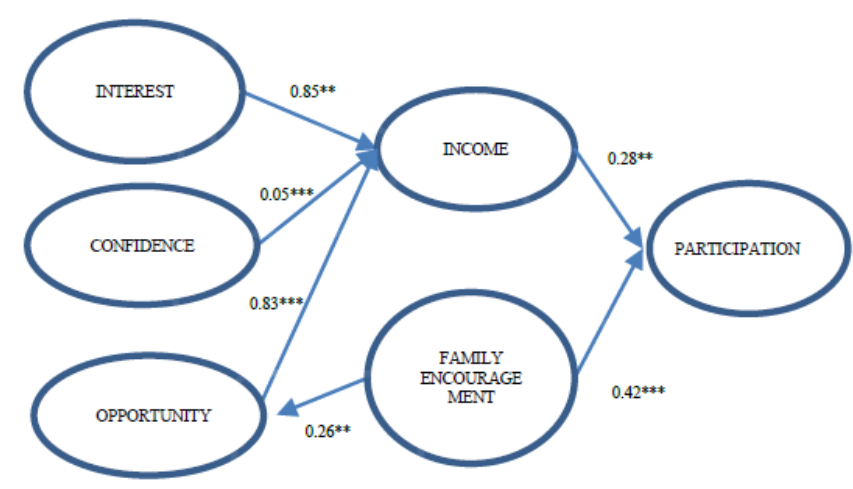

Fig. 4. The empirical model.

\section{POLICY IMPLICATION AND CONCLUSION}

This study shows that tourism development should be integrated with community involvement. This is important because entrepreneurs and business activities serve as catalysts for economic development [13], [28] as well as guarantors to the continuity of the economy in this island. The community has gained the benefit [14] from the tourism development especially in terms of, as source of employment and income growth as well as to ensure the sustainability of the tourism industry.

To further enhance community participation in tourism related business, the factors that serve as stimulants to this involvement are important to be noted. This is the objective of this study as well as to discover the profile and types of local communities' businesses in tourism.

The results showed that the involvement of local communities in tourism-related business is influenced by two main factors, namely income and family encouragement. These factors are also aided by confidence, interests and opportunities available in Langkawi.

Thus, as a policy implication in further stimulating community involvement in tourism related business, the local 
communities must be made aware of the opportunities to earn or increase their income through tourism related businesses. They also need to be exposed to the opportunities available. Additionally, they are also to continuously receive the support from family members, institutions or government; as well as the increase in confidence and interest factors. These factors could also be synergized and are believed to increase community involvement in tourism related business, particularly on the island of Langkawi.

\section{ACKNOWLEDGMENT}

This research was supported by the National University of Malaysia through Research Grant Scheme GRANT: PIP-UKM-2013-001.

\section{REFERENCES}

[1] R. E. Mitchell and D. G. Reid, "Community integration: Island tourism in Peru," Annals of Tourism Research, vol. 28, no. 1, pp. 113-139, 2001.

[2] P. Garegnani. (2013). Note on Consumption, Investment and Effective Demand. [Online]. Available: http://cas.umkc.edu/econ/economics/ faculty/Forstater/506/506readings/ garegnani.pdf

[3] N. H. M. Salleh, R. Othman, S. H. M. Idris, A. H. Jaafar, and D. P. Selvaratnam, "The effects of tourism development towards livelihood sustainability of the Orang Asli at the Kg. Sg. Ruil, Cameron Highlands," Tourismos, vol. 8, no. 2, pp. 301-321, 2013.

[4] G. L. Murphy and D. L. Medin, "The role of theories in conceptual coherence," Psychological Review, vol. 92, no. 3, pp. 289, 1985.

[5] J. Zhangand and F. Y. Kai, "What's the relative risk? A method of correcting the odds ratio in cohort studies of common outcomes," Jama, vol. 280, no. 19, pp. 1690-1691, 1998.

[6] G. F. George, "Entrepreneurship; Capitalists and financiers," United States, 1984

[7] T. Atanassova, "Enterprising management in the Agrarian sector of Bulgaria," Macedonian Journal of Animal Science, vol. 1, no. 2, pp. 401-406, 2011.

[8] G. Ranis, F. Stewart, and A. Ramirez, "Economic growth and human development," World Development, vol. 28, no. 2, pp. 197-219, 2000.

[9] K. Andriotis, "Community groups' perceptions of and preferences for tourism development: Evidence from crete," Journal of Hospitality \& Tourism Research, vol. 29, no. 1, pp. 67-90, 2005.

[10] A. Clayton, P. Oakley, and B. Pratt, "Empowering People: A guide to participation," United Nations Development Programme, vol. 10, no. 2-3, pp. 144-164, 1998

[11] I. Pepper, Crime Scene Investigation: Methods and Procedures: Methods and Procedures, McGraw-Hill International, 2010.

[12] G. Taylor, "The community approach: does it really work?" Tourism Management, vol.16, no. 7, pp. 487-489, 1995.

[13] S. F. McCool and S. R. Martin, "Community attachment and attitudes toward tourism development," Journal of Travel Research, vol. 32, no. 3, pp. 29-34, 1994.

[14] N. H. M. Salleh, R. Othman, T. Sarmidi, and Z, Darawi, "A comparison of local community sustainability of livelihood: A case study in Redang and Tioman Islands, Malaysia," in Proc. the 2011 IEEE International Summer Conference of Asia Pacific, Business Innovation and Technology Management (APBITM), pp. 144-148, 2011.

[15] H. A. Tatham, J. F. Hair, R. E. Anderson, and R. L. Tatham, "Black WC," Multivariate Data Analysis, 1998.

[16] J. F. Hair, Research Methods for Business, 2007.

[17] L. W. Turner and Y. Reisinger, "Shopping satisfaction for domestic tourists," Journal of Retailing and Consumer Services, no. 8, vol. 1, pp. $15-27,2001$.

[18] G. R. Shi, M. S. Leman, and B. K Tan, "Early Permian brachiopods from the Singa Formation of Langkawi Island, northwestern Peninsular Malaysia: biostratigraphical and biogeographical implications," in Proc. International Conference on Stratigraphy and Tectonic Evolution of Southeast Asia and South Pacific and the Associated Meetings of IGCP, vol. 359, pp. 62-72, 1997.
[19] A. S. Uyar and N. Deniz, "The perceptions of entrepreneurs on the strategic role of human resource management," Procedia-Social and Behavioral Sciences, vol. 58, pp. 914-923, 2012.

[20] M. Jaafar, A. R. A. Aziz, S. A. Maideen, and S. Z. Mohd, "Entrepreneurship in the tourism industry: Issues in developing countries," International Journal of Hospitality Management, no. 30, vol. 4, pp. 827-835, 2011.

[21] K. G. Jöreskog and D. Sörbom, LISREL 7: A Guaide to the Program and Applications, Chicago: Spss., vol. 2, 1989.

[22] N. Deniz, I. T. Boz, and O. G. Ertosun, "The relationship between entrepreneur's level of perceived business-related fear and business performance," Procedia-Social and Behavioral Sciences, vol. 24, pp. $579-600,2011$

[23] M. B. A. Kadir, M. Salim, and H. Kamarudin, "The relationship between educational support and entrepreneurial intentions in malaysian higher learning institution," Procedia-Social and Behavioral Sciences, vol. 69 pp. 2164-2173, 2012.

[24] A. A Gunawan, "Preliminary study of classifying indonesian entrepreneurs," Procedia-Social and Behavioral Sciences, vol. 115, pp. 243-250, 2014.

[25] F. Gilder and George, Entrepreneurship, Capitalists and Financiers, United States, 1984.

[26] A. Todorka, "Enterprising management in the agrarian sector of bulgaria," Department of Management, Trakia University, Stara Zagora, Bulgaria, pp. 403-404, 2009.

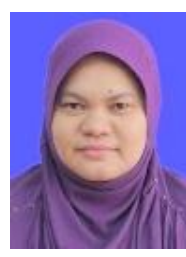

Norlida Hanim Mohd Salleh is an associate professor at the School of Economics, Faculty of Economics and Management, UKM. She just returned to Universiti Kebangsaan Malaysia after furthering her education in at the doctorate level in Universiti Putra Malaysia. Her Ph.D research focused on the "Inbound Tourism Demand for Malaysia". Her specialization is on tourism economics and natural resource and environmental economics.

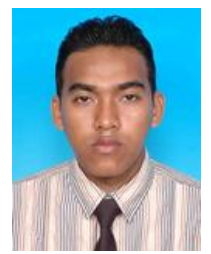

Shafiin Shukor received his diploma in Islamic Banking from Kolej Universiti Islam Antarabangsa Selangor in 2008. In 2010-2014, he persued his study at Faculty of Economics and Management, UKM and received his bachelor and masters in environmental and natural resource. In 2015, with the same field of studyhe continue his doctorate (Ph.D) at Faculty of Economics and Management, UKM.

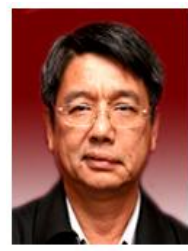

Redzuan Othman is an associate professor at the School of Economics, Faculty of Economics and Business, UKM. He received his Ph.D from the West Virginia University in agriculture economics. His research areas are mainly on tourism economics and resource and environmental economics.

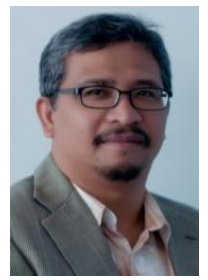

Mohd Bin Samsudin is a senior lecturer and the head of history program at the Centre for History Studies, Politics and Strategy, the Faculty of Social Science and Humanities, Universiti Kebangsaan Malaysia (UKM). His field of expertise is Malaysia history and heritage and conservation. He has been actively involved in local and international research relating to national history, Malaysia's development and heritage and conservation. $\mathrm{He}$ is a currently director of the Museum of Academic

Heritage, UKM

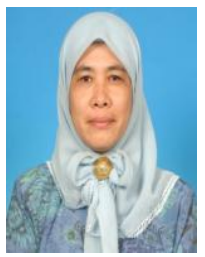

Siti Hajar Mohd Idris is a senior lecturer at the School of Economics, Faculty of Economics and Business, UKM. She specializes in mathematical economics and teaches mathematics and research methodology for undergraduate students. She graduated with a degree of science in mathematics and master in economics from Western Illinois University, USA. 